University of Nebraska - Lincoln

DigitalCommons@University of Nebraska - Lincoln

Nebraska Cooperative Fish \& Wildlife Research Nebraska Cooperative Fish \& Wildlife Research Unit -- Staff Publications

2020

\title{
Use and expenditures on public access hunting lands
}

Lyndsie S. Wszola

University of Nebraska-Lincoln, lyndsie.wszola@huskers.unl.edu

Lutz F. Gruber

University of Nebraska-Lincoln, lutz.gruber@unl.edu

Erica F. Stuber

University of Nebraska-Lincoln, efstuber@gmail.com

Lindsey N. Messinger

Minnesota Department of Natural Resources, lindsey.messinger@state.mn.us

Christopher J. Chizinski

University of Nebraska-Lincoln, cchizinski2@unl.edu

See next page for additional authors

Follow this and additional works at: https://digitalcommons.unl.edu/ncfwrustaff

Part of the Aquaculture and Fisheries Commons, Environmental Indicators and Impact Assessment Commons, Environmental Monitoring Commons, Natural Resource Economics Commons, Natural

Resources and Conservation Commons, and the Water Resource Management Commons

Wszola, Lyndsie S.; Gruber, Lutz F.; Stuber, Erica F.; Messinger, Lindsey N.; Chizinski, Christopher J.; and Fontaine, Joseph J., "Use and expenditures on public access hunting lands" (2020). Nebraska Cooperative Fish \& Wildlife Research Unit -- Staff Publications. 301.

https://digitalcommons.unl.edu/ncfwrustaff/301

This Article is brought to you for free and open access by the Nebraska Cooperative Fish \& Wildlife Research Unit at DigitalCommons@University of Nebraska - Lincoln. It has been accepted for inclusion in Nebraska Cooperative Fish \& Wildlife Research Unit -- Staff Publications by an authorized administrator of DigitalCommons@University of Nebraska - Lincoln. 


\section{Authors}

Lyndsie S. Wszola, Lutz F. Gruber, Erica F. Stuber, Lindsey N. Messinger, Christopher J. Chizinski, and Joseph J. Fontaine 


\title{
Use and expenditures on public access hunting lands
}

\author{
Lyndsie S. Wszola, ${ }^{1}$ Lutz F. Gruber, ${ }^{1}$ Erica F. Stuber, ${ }^{1}$ \\ Lindsey N. Messinger, ${ }^{2}$ Christopher J. Chizinski, ${ }^{3}$ \\ \& Joseph J. Fontaine 3
}

\author{
1 Nebraska Cooperative Fish \& Wildlife Research Unit, University of Nebraska- \\ Lincoln, USA \\ 2 Farmland Wildlife Populations and Research Group, Minnesota Department \\ of Natural Resources, USA \\ 3 School of Natural Resources, University of Nebraska-Lincoln, USA \\ Corresponding author - L. S. Wszola, 406 Manter Hall, University of Nebraska-Lincoln, \\ Lincoln, NE, 68508, USA. Email lyndsie.wszola@huskers.unl.edu
}

\begin{abstract}
The recreational and economic benefits of hunting on traditional permanent public lands are well-established. Increasingly popular "open fields" hunting access programs temporarily open private lands to public hunting through public-private partnerships. Open fields programs have the potential to create public hunting opportunities and economic development in rural communities, but the extent to which open fields programs compare to traditional public lands at providing benefits to hunters and rural communities has not yet been evaluated. We compared hunter use and expenditures on open fields lands and traditional public lands in Nebraska, USA. We used Convolution Likelihood Ecological Abundance Regression, a novel Bayesian abundance estimation method, to predict hunter effort, target species, and total expenditures using combined inferences from hunter count surveys, camera traps, and extensive in-person interviews. Open fields sites generally provided
\end{abstract}

Published in Journal of Outdoor Recreation and Tourism 29 (2020), 100256.

DOI: 10.1016/j.jort.2019.10025

Copyright 2213-0780/ (C) 2019 Elsevier Ltd. Used by permission.

Submitted 7 November 2018; revised 21 August 2019; accepted 12 September 2019;

published 19 November 2019. 
lower hunter use and expenditure returns per unit area than did traditional public lands. However, open fields and traditional public lands provided similar returns in one study region prioritized for highly-publicized upland gamebird opportunities. Our findings demonstrate that open fields programs can create returns in use and hunter expenditures when paired with strategic communication initiatives and further suggest that access programs may benefit from enrolling properties that provide diverse opportunities. Management implication: The study shows, that public access hunting lands near urban areas receive relatively high use, but hunter expenditures may be greater in ecological rich rural areas. Public-private hunting access partnerships can create returns in hunter use and expenditures when they provide access to valued, highly publicized hunting opportunities.

Keywords: Human dimensions, R3, Hunting, Hunter expenditures, Hunter use, Open fields, Social-ecological systems

\section{Introduction}

Outdoor recreation opportunities in rural communities provide recreational benefits for recreationists and economic benefits for the communities themselves (West \& Merriam, 1970; reviewed in; Machlis \& Field, 2000; Zabriskie \& McCormick, 2004; Maller, Townsend, Pryor, Brown, \& St Leger, 2005; Rosenberger, Sneh, Phipps, \& Gurvitch, 2005; Mayer, Müller, Woltering, Arnegger, \& Job, 2010; Hamzah \& Khalifah, 2012). However, most rural communities in the United States are located far from flagship public lands, ostensibly limiting the benefits of public recreation opportunities for rural communities nationally. Responding to a need for public hunting opportunities, state wildlife agencies are increasingly supplementing traditional purchase-based land access strategies with public-private partnerships that open private lands to public hunting for a contract-determined time period (Helland, 2006; Ribot \& Peluso, 2009). Public access programs that lease private lands for public hunting access, namely "Open fields" programs, can greatly increase the area of public access hunting land in states with limited public land ownership by enrolling many smaller properties to supplement larger traditional public lands. For example, the area of publicly accessible hunting land in Nebraska and Kansas, agricultural states with relatively little public land, is effectively doubled by their open fields programs (Nebraska Game and Parks Commission [NGPC], 2017a; Kansas Department of Wildlife, Parks, and Tourism, 2017). For clarity, we use the term "public access" 
for all locations where public hunting is allowed for any time period. We further distinguish "traditional public lands" permanently open for public use from privately owned "open fields" lands temporarily opened to public hunting through public-private partnerships.

Given the benefits of public access hunting, increasing public access availability, even temporarily, might provide additional benefits to rural communities; however, the benefits of open fields programs remain largely unexplored. If investment in public access is to create positive economic outcomes for rural communities, a frequently stated objective of open fields programs (U.S. Government Office of Management and Budget; NGPC, 2016), we must identify factors that affect the returns from open fields programs to rural communities and the hunting public. Among the many facets of value that public access lands provide to recreationists and communities, two of the most frequently examined are hunter use of public access lands and hunter expenditures while traveling to and hunting on public access lands. (Arnett \& Southwick, 2015). Hunter use is often quantified as the number of hunter-use days a site receives (e.g., Burger, 2000). Public access hunting lands may also be evaluated by their ability to spur hunter expenditures that contribute to rural economies through services used by traveling hunters (Poudel, Henderson, \& Munn, 2016). Herein, we compare hunter use and expenditures on traditional public lands to annually-enrolled open fields properties in Nebraska, USA to understand how social and ecological variation among hunters and hunting destinations contributes to varying returns from hunting access programs.

\section{Conceptual framework and literature review}

\subsection{Conceptual framework}

Sportspersons navigate complex social-ecological environments when choosing where and with whom to recreate and how much to spend while recreating (Beardmore, Hunt, Haider, Dorow, \& Arlinghuas, 2015; Hunt, Sutton, \& Arlinghaus, 2013; Larson, Stedman, Decker, Siemer, \& Baumer, 2014; Von Essen, 2018). We have drawn on the following literature review to create a conceptual framework 
(Fig. 1) placing our focused assessment of hunter use and expenditures in the larger context of hunting as a social-ecological system. In our framework, hunter decisions about what to hunt (target species), where to hunt (site), how long to stay (trip length), and where to stay (lodging) result from attributes of hunters (Fig. 1a), such as hunter age and recreational specialization, (the hunter's specific combination of motivation, involvement, and skill in their chosen activity; Bryan, 1977) and those of destinations (Fig. 1b), such as target species abundance and amenities like camp sites and restaurants. Hunter use and expenditure decisions create outcomes for hunters (Fig. 1c) such as harvest, satisfaction (the extent to which a hunt meets or exceeds expectations; Oliver, 1980), and future intention to hunt that, in turn, affect future hunter attributes (Fig. 1f). Hunter decisions and outcomes likewise affect destination outcomes (Fig. 1d-e) such as total hunter use and expenditures, and impacts on wildlife populations, that in turn feed back into destination attributes (Fig. 1g).

Previous work has identified factors that, while not assessed in our study, form vital parts of the larger social-ecological system. Hunter attributes such as social environment (the involvement in and opinions of hunting held by the hunter's community; Larson, Stedman, Decker, Siemer, \& Baumer, 2014) and hunting experience, and destination attributes, such as natural beauty or aesthetic appeal, may influence hunter use decisions. Likewise, though we do not explicitly examine the feedbacks from hunter outcomes to future hunter attributes, or from destination outcomes to destination attributes, understanding the larger social-ecological system remains essential to contextualizing and applying relationships between landscapes, hunters, and larger social trends. In the literature review below, we examine proposed moderators of hunter target species, site, trip length, and lodging decisions to inform our focused examination of how hunter and destination attributes inform hunter decisions and use and expenditure outcomes for hunters and destinations. We focus on attributes of hunters and destinations that manifest in individual hunter target species, site, trip length, and expenditure decisions because these decisions determine hunter site use and expenditures. We then estimate the outcomes for hunters and destinations, discuss the likely importance of hunter use and expenditure decisions for the future of hunting as a social-ecological system, and finally explore prospects for future research. 


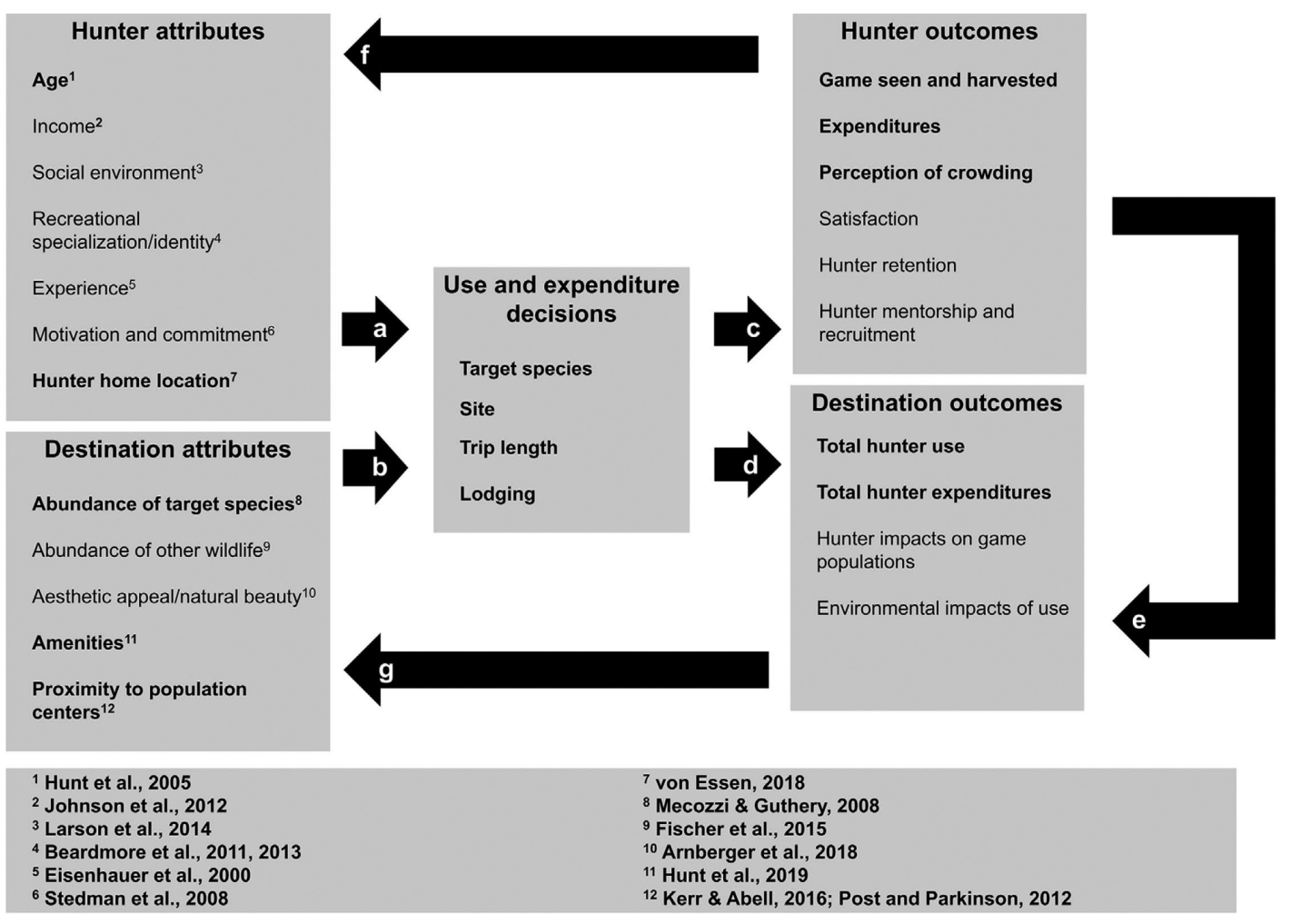

Fig. 1. Conceptual framework. Our examination of hunter use and expenditures, while narrow in scope, occurs in the context of a much larger and more complex social-ecological system. This study investigates how attributes of hunters and destinations drive hunter target species, site, trip length, and lodging decisions $(a, b)$ that scale up to outcomes for hunters (c) and destinations (d). The cumulative hunter outcomes affect the outcomes for the destination (e), and future hunter attributes (f). Destination outcomes, in turn, feedback into the destination attributes (g). The elements of this system assessed in the manuscript are emphasized in bold font. Selected references are indicated via superscripts.

\subsubsection{Target species decisions}

A hunter's decision of what target species to pursue is a potentially important moderator of both hunter site choice and expenditures, and itself a function of the interaction between hunter and destination attributes. Hunter age, motivation, and social environment may interact with the abundance of different potential target species to determine target species decisions (Papworth, Rist, Coad, \& MilnerGulland, 2009). Hunting is inherently social, and hunting companions often stay together for decades (Muth \& Jamison, 2000). Hunters motivated by harvesting their target species may begin pursuing a 
target species in a time when it is abundant, and reduce participation in that activity when their target species declines in abundance (Enck, Swift, \& Decker, 1993). However, hunters who form hunting companion relationships around one target species may persist in hunting that target species together because it allows them to maintain their relationships, regardless of the current abundance of that target species (Bronner, 2004). Hunter target species decisions may therefore reflect the hunting conditions that were available when hunters began hunting, rather than the current conditions. In the United States, for example, older hunters who began hunting in the 1950's to 1980's would have encountered abundant upland bird populations and relatively scarce waterfowl populations, whereas younger hunters who began hunting in the 1990's to 2000's would have encountered scarce upland bird populations and abundant waterfowl (U.S. Fish and Wildlife Service, 2018).

Essential to this dynamic is the social environment in which hunting occurs, motivations for hunting, and the hunter's financial status. Hayslette, Armstrong, and Mirarchi (2001) found that early socialization was important to predicting future participation in dove hunting, and that dove hunters were primarily motivated by fellowship with their hunting companions. Similarly, Bhandari, Stedman, Luloff, Finley, and Diefenbach (2006) found that hunter motivation affected hunter likelihood of harvesting antlerless deer; hunters who harvested antlerless deer were more likely to view hunting as a management tool and be motivated by harvesting venison than those who harvested an antlered deer. The experiences hunters build interacting with wildlife populations and each other give rise to the development of skills and experience that can lead to specialization in one or a few species, and future participation in hunting that species (Miller \& Graefe, 2000). For example, waterfowl hunters who specialize in waterfowl hunting may form a waterfowl hunter identity and become more likely to persist in waterfowl hunting (Schroeder, Fulton, Lawrence, \& Cordts, 2013). However, a hunter's propensity to continue hunting a particular species is predicated upon their ability to afford it. Some hunting activities, like waterfowl hunting, are much more expensive than others, like small game hunting, even without travel costs (U.S. Fish and Wildlife Service, 2018). The decline of once-common species has also made it more difficult and expensive for hunters to target those 
species, creating a new relationship between hunter income and likelihood to pursue animals like quail. For example, Johnson, Rollins, and Reyna (2012) found that participation in quail hunting has declined slower among affluent hunters than non-affluent hunters because affluent hunters are more capable of paying for access to private lands where quail are more abundant and hunting competition more controlled.

\subsubsection{Site choice decisions}

Individual hunters' use decisions scale to patterns of land use at the landscape scale, driving variation in the overall use value of public access hunting lands (Adamowicz, Jennings, \& Coyne, 1990; Hunt, Arlinghaus, Lester, \& Kushneriuk, 2011; Lone et al., 2014). If we are to compare the use value of open fields properties to that of traditional public lands, we must first identify the social and ecological traits of hunters and hunting destinations that drive hunter use decisions. Much of the theory regarding variation in sportsperson site choice at the landscape scale originates in the recreational fisheries literature. Because hunters and anglers share many characteristics, and indeed fishing may serve as a substitute activity for hunting (Needham \& Vaske, 2013), combining the theoretical understanding of hunting demand from the hunter literature with the landscape-scale theory and site choice models from the fisheries literature creates the basis for hypotheses about how the choices of individual sportspersons scale to create landscape patterns of use. Hunt et al. (2005a; 2005b; 2007) developed a social-ecological framework of sportsperson site decision making that incorporates ecological (e.g., habitat condition, game abundance) and social (e.g., costs, amenities, competition, and regulations) factors. The importance of ecological factors is intuitive, but it is increasingly apparent that social context plays a significant role in shaping the opportunities recreationists pursue (Metcalf, Graefe, Trauntven, \& Burns, 2015).

Beardmore, Haider, Hunt, and Arlinghaus (2011; 2013) demonstrated that sportspersons have diverse motivations for seeking locations to recreate and display varying levels of commitment to the sport, a dynamic that proves to be particularly important for hunters as well as anglers (Kerr \& Abell, 2016; Manfredo, Fix, Teel, Smeltzer, 
\& Kahn, 2004). Sportspersons' motivations and commitment may interact with destination attributes to determine where sportspersons choose to recreate. For example, avid boat anglers respond to the distribution of their target fish, but casual or non-angling boaters choose spaces near recreational infrastructure (Hunt et al., 2019b). These decisions have consequences for the resources chosen. For example, when anglers respond to both travel cost and fishing quality, fisheries resources near urban areas may be more heavily exploited than those in rural areas (Post \& Parkinson, 2012).

Hunters may make site choice decisions based on tradeoffs between their target species, the perceived relative abundance of the target species in different potential hunting destinations, and the hunters' own recreational specialization, experience, social environment, age and income. Hunters who are motivated by seeing and harvesting their target species, especially those with a high degree of recreational specialization in their chosen activity, may expend time and energy to reach destinations with high target species abundance, regardless of cost (Kerr \& Abell, 2016). Similarly, hunters motivated by more holistic experiences of hunting may furthermore choose hunting destinations that allow them to enjoy other aspects of hunting, such as the opportunity to see non-target wildlife and appreciate a destination's natural beauty (Arnberger et al., 2018). Hunters may make tradeoffs between the distribution of game abundance and travel costs or other risks depending on their objectives and motivations (Mecozzi \& Guthery, 2008; Stedman, Bhandari, Luloff, Diefenbach, \& Finley, 2008). Truong, Adamowicz, \& Boxall, 2018 demonstrated that hunters aware of the distribution of chronic wasting disease may shift their site choice to avoid hunting affected areas, while Pang (2017) showed that big game hunters would be willing to spend more in travel costs for an increased likelihood of harvesting a target animal. In addition to monetary travel costs, hunters may be sensitive to opportunity cost, the loss of time to pursue other recreation options incurred by choosing a given option, of potential hunting sites and choose sites they perceive to have a relatively low opportunity cost (Devers, Roberts, Knoche, Padding, \& Raftovich, 2017; Whitten \& Bennett, 2002).

Because open fields properties are enrolled annually, they may present an unknown quantity with a high perceived opportunity cost, especially for hunters with limited recreational time. Hunters with limited 
means or those motivated by spending time with family may choose locations closer to home, even at the cost of encountering fewer of their target species. Hunters may also choose to pursue sites based on their social environment. Those with longstanding traditions on particular public lands may choose to return there to engage in the sport with their hunting companions regardless of target species abundance or cost. Finally, hunters may be influenced in their site choice by the interaction between their own social environment and motivations, and a potential hunting destination's amenities and proximity to their home. Hunters looking for opportunities close to home or prioritizing time with children, who themselves have limited recreational time, may choose hunting destinations close to the population centers in which they reside. Likewise, sportspersons hunting with children or older people may choose destinations that provide amenities like hotels, restaurants, and even restrooms on public lands, rather than more remote and less developed destinations (Harmon, 2017). Because social and ecological variation occurs across space, geographic regions represent variation in target species availability and abundance, as well as proximity to different hunter home locations and potential for hunter experience with the landscape and each other. Traditional public and open fields lands may offer similar tradeoffs.

\subsubsection{Trip length decisions}

Trip length, the number of days a hunter spends on a given hunting trip, is an essential component of understanding the hunter experience and estimating hunter expenditures. The number of days a hunter travels during a hunting trip determines how much they need to spend to support themselves while traveling. Trip length may be affected by interactions between hunter and destination attributes, particularly hunter target species, motivation, social environment, age, and income, and destination target species abundance, amenities, and the relative locations of the hunter's home and the hunting destination.

The hunter social environment is certainly important to determining trip length. Hunters with long-standing hunting companion relationships may hunt more often and be more likely to embark on longer trips because longer trips allow them to engage in fellowship with 
their hunting companions (Stedman, Bhandari, Luloff, Diefenbach, \& Finley, 2008). On a similar note, hunters with young children may be less likely to make longer trips due to family responsibilities and lack of disposable income, whereas hunters with children of hunting age, adult children, or no children, may be more likely to make longer trips because they wish to share the experience with their children or do not have significant childcare or child-related financial responsibilities (Metcalf et al., 2015). Likewise, older hunters may be past retirement age and able to devote more time and disposable income to recreation, whereas younger hunters may have greater work and childcare responsibilities and find themselves unable to justify the time and expense of an extended hunting trip (Nicolaisen, Thorsen, \& Eriksen, 2012; U.S. Fish and Wildlife Service, 2018). Winkler and Warnke (2013) demonstrated that age may play a strong role in hunter participation via a cohort effect; hunters who started hunting in the mid-twentieth century experienced a social environment favorable to hunting that has not been replicated for later generations. Hunting participation and hunting trip length may also vary as a function of income (Heberlein, Ericsson, \& Wollscheid, 2002, but see; Heberlein, Serup, \& Ericsson, 2008). Hunters with more disposable income may be more likely to make longer trips because they may justify the expense, a luxury not possible for lower-income hunters (Shrestha \& Burns, 2016). Hunters who do have the time and disposable income to plan longer hunting trips may consequently adjust their decisions based on the travel amenities such as hotels and restaurants, and other attractions such as watchable wildlife, available in a potential destination (Arnberger et al., 2018; Hunt, Camp, van Poorten, \& Arlinghaus, 2019a).

Finally, trip length may be determined by the interaction between target species, target species abundance at a hunting destination, hunter motivation and commitment, and proximity of the destination to population centers, i.e., the hunter's home location. Because ecosystems vary across space, different hunting opportunities are available in different areas. Hunters seeking a target species only found at some distance from their home must necessarily make longer trips, and hunters may adjust trip length according to their motivations and levels of commitment. For example, once-common species such as ring-necked pheasants (Phasianus colchicus) and northern bobwhites 
(Colinus virginianus) have declined across their range (Hernández, Brennan, DeMaso, Sands, \& Wester, 2012; Hiller, Taylor, Lusk, Powell, \& Tyre, 2015). The result of such population declines is that a traditionally low-cost hunting activity has evolved into a hunting activity that requires many hunters to make tradeoffs between hunting scarce populations close to home on short trips, or traveling on longer trips for more abundant populations. Whether hunters embark on longer trips may depend on their motivations. For example, a hunter motivated by mentoring youth hunters may be content with a shorter trip closer to their home, even if it means lower target species abundance, whereas a hunter motivated by harvest may be willing to pursue longer trips to areas with high target species abundance (Schultz, Millspaugh, Zekor, \& Washburn, 2003).

\subsubsection{Lodging decisions}

Some hunting expenses, such as fuel costs, are likely to be solely determined by trip length and the distance from a hunter's home to a hunting destination. Others, like food and lodging costs, are likely to be a function of the hunter's decisions of where to stay. There are categorically four options of where hunters may stay, depending on their trip length, relative locations of their home and hunting destination, destination attributes, hunter motivation, and social environment: hunters may stay in their own homes, in the home of a family member or friend, in a hotel or other paid lodging, or at a camp site. Hunters engaging in short day trips will most likely stay in their own home, spending no extra money on lodging or food. Hunters traveling on longer, multi-day trips must either stay in the home of a member of their social circle, in paid lodging, or at a camp site. Whether hunters have the ability to stay in the home of a social associate is largely determined by the extent of their social network in the hunting destination, a dynamic that also has a powerful effect on hunter access (Holsman, Beardmore, Bradshaw, \& Petchenik, 2018). If hunters must, or prefer to, stay in paid lodging, their choice of lodging may be affected by hunter age, income, recreational identity, and a destination's available amenities and natural beauty.

Rural areas often experience unusually large influxes of visitors during popular hunting seasons, and may only be able to offer a small 
number of paid rooms to visitors, often at an inflated rate. Younger and fitter hunters, those with more limited financial means, and those traveling to hunting destinations with limited paid lodging opportunities may therefore be more likely to camp when campsites are available (White et al., 2016). Likewise, hunters whose identities and objectives lead them to prize the aesthetic values of hunting sites, such as seeing other wildlife or enjoying a destination's natural beauty, may choose to camp to enhance their outdoor experience (Coker et al., 2018). Conversely, hunters with more available financial means and physical need may be more likely to pay for lodging such as at a hunting lodge or hotel (Zhang, Hussain, \& Armstrong, 2006).

\section{Research objectives}

Conservation decision makers seeking to make optimal use of limited land management funds are often tasked not only with facilitating hunter participation but also with spurring rural economic development through hunter expenditures. Many assessments of hunter expenditures while traveling for and engaging in hunting have demonstrated that hunter expenditures on food, fuel, lodging, and equipment can have a significant economic impact on rural economies (Arnett \& Southwick, 2015; Bilgic, Florkowski, Yoder, \& Schreiner, 2008; Grado, Hunt, Hutt, Santos, \& Kaminski, 2011; Holmes et al., 2015; Munn, Hussain, Spurlock, \& Henderson, 2010). Because of the potential for hunter expenditures to contribute to rural economic development, strategies for optimizing hunter expenditures have been the subject of much discussion (e.g., Burger, Miller, \& Southwick, 1999; Wallace, Stribling, \& Clonts, 1991). Hunter expenditures in rural economies often create a net positive effect for hunters and rural economies, but some authors (e.g., Adams, Bergland, Musser, Johnson, \& Musser, 1989; Shrestha \& Burns, 2016) have noted that the participation costs for an increasingly urban hunting constituency to access rural locations can be a significant barrier to participation in hunting, and may limit the value of providing hunting opportunities that are costly to access. Access strategies that count on the willingness of hunters to pay more financial and opportunity costs to increase harvest success may fail if they do not account for how costs affect participation. 
The willingness of a hunter to incur costs for the opportunity to pursue game ultimately reflects both the opportunity provided and ability to pay. Hunters may be willing to spend more to reach unique opportunities, like western big game species for eastern hunters, or for species that were once abundant nationwide and have declined in many areas, like pheasants and quail. For example, (MacKenzie, 1990) demonstrated that hunters are willing to pay more in monetary and opportunity costs for the increased likelihood of harvesting a deer. However, no hunter can spend money that they do not have, creating a difficult situation for land managers seeking to optimize hunter participation and rural economic development with finite land management resources. Herein, we seek to understand social and ecological correlates of variation in the hunter use and expenditure returns provided by traditional public lands and emerging, annually-enrolled open fields lands. Our research objectives were:

1. To determine how hunter use of traditional public and open fields land varied by social-ecological region and time of the year.

2. To assess how hunter expenditures varied in relation to target species, hunter age, hunter travel distance, and socialecological region.

3. To compare total returns in hunter use and hunter expenditures between open fields and traditional public lands in different social ecological regions.

\section{Methods}

\subsection{Study area and data collection}

We assessed hunter use, demographics, and expenditures from 1 September to 31 January 2014-2015, 2015-2016, and 2016-2017, a time period that included all major fall hunting seasons in Nebraska: upland birds, deer, turkey, and ducks. "Upland birds" primarily referred to ring-necked pheasants (Phasianus colchicus) and also included northern bobwhites (Colinus virginianus), sharp-tailed grouse (Tympanuchus phasianellus) and greater prairie chickens (Tympanuchus cupido). "Ducks" included all legally harvestable duck species, 


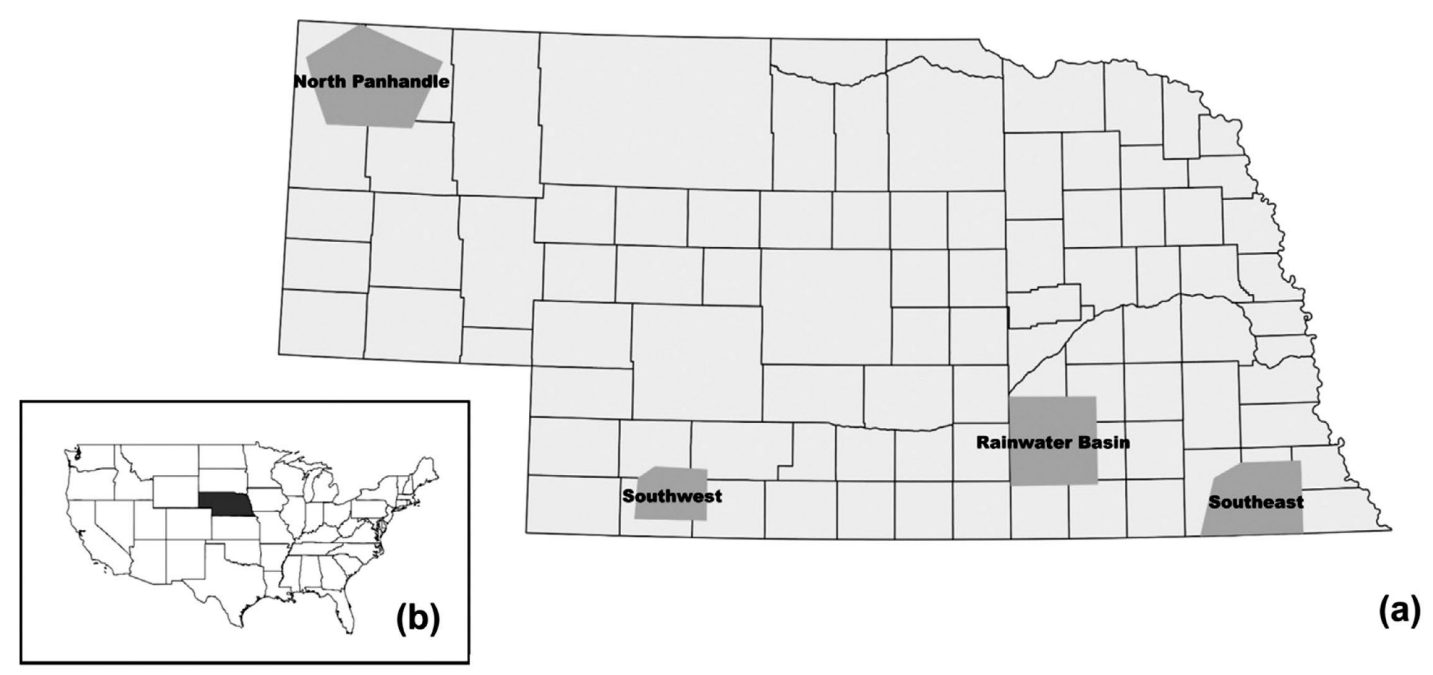

Fig. 2. Hunter interview and count data was collected in four study regions in $\mathrm{Ne}-$ braska (a), USA (b) from 1 September - 31 January 2014-2017. The North Panhandle region lacked significant urban development and provided opportunity for turkey, mule deer, and white-tailed deer. The Southwest region again lacked significant urban development and offered opportunity for mule deer, white-tailed deer, turkey, and the state's highest density of upland birds. The Rainwater Bain region was located between Grand Island, Hastings, and Kearney, three of Nebraska's larger (25,000-50,000 residents) towns and provided opportunity for waterfowl and upland birds. The Southeast region was located between Lincoln and Omaha, which together comprise $65 \%$ of Nebraska's population (U.S. Census Bureau, 2018) and provided opportunity for deer, turkey, and upland birds.

"turkey" refers to wild turkey (Meleagris gallopavo), and "deer" included mule deer (Odocoileus hemionus) and white-tailed deer (Odocoileus virginianus).

The study area included four regions in Nebraska, USA (Fig. 2) that varied in the number and land area of public access sites, the composition of public access ownership, human population density and infrastructure, and game species abundance (U.S. Census Bureau, 2010; NGPC, 2017a-d; NGPC 2018a-c). We defined sampling locations as a Public Land Survey System sections of land (i.e., square mile; U.S. Geological Survey, 2018) that included any open fields or traditional public land. No sampling location was larger than a single section, but multiple sampling locations could be adjacent (NGPC, 2017a). Information on the distribution of all sites was widely distributed by the Nebraska Game and Parks Commission in the Public Access Atlas, 
a free, annually-updated gazetteer of thematic public access hunting maps, including traditional public and open fields properties (NGPC, 2017a). The Public Access Atlas is distributed at hunting license sales locations, state offices, and many other public spaces such as grocery stores and gas stations. The Atlas is also available online and as a GIS file that may be added to mobile navigation applications. NGPC additionally makes available supplemental maps and advertising about the Southwest study region, which supports the state's most abundant upland bird populations (NGPC, 2017d).

Sites were visited daily in a systematic bus-route design that randomized start time (morning or afternoon), start location (3-5 start locations per route), and route direction (clockwise or counter-clockwise; Pollock, Jones, \& Brown, 1994). Morning routes started at the beginning of legal hunting hours (30 min before sunrise) and continued until noon. Afternoon routes began between 12:30 and 13:30, adjusting seasonally to create an 8-h sampling block that ended 30 min after sunset, the end of legal hunting hours. Sites with an available elevated structure (e.g., a pole or dead tree) were additionally monitored using time-lapse photography. Trail cameras (Moultrie M-880 Digital Game Camera) positioned at a height of $4-5 \mathrm{~m}$ from the ground facing parking areas were programmed to record an image every 5 min from sunrise to sunset daily for the duration of each hunting season of the study. We used Timelapse (Greenberg \& Godin, 2015) to extract the number of vehicles visible in each image.

We interviewed visitors exiting public access sites daily following a standardized protocol similar to a traditional creel survey (Pollock et al. 1994). Interview questions pertained only to the site where hunters were encountered and aimed at identifying: 1) number of participants and vehicles per party, 2) visitor demographics including sex, age, and home ZIP code, 3) outdoor activity and specific target species group (e.g., deer hunting, duck hunting), 4) trip length, 5) choice of lodging, 6) game animals seen and harvested, and 7) crowdedness rating (1, "Very crowded" to 5, "Not crowded at all"). Hunters were assigned a target species group based on their primary reported target species during the hunt immediately preceding their interview, regardless of the species they harvested. We interviewed only parties that included at least one individual aged 19 or older, per institutional human subjects' policy, and conducted all work under IRB approval 
20120912892EX from the University of Nebraska-Lincoln. We assigned hunters an estimated population density per square kilometer of land area based on their reported home ZIP code and the 2016 American Community Survey (U.S. Census Bureau, 2016, p. 2016).

\subsection{Daily per capita hunter expenditures}

Because Nebraska's different social-ecological regions offer different resources that may attract hunters with different objectives and subsequently evoke different hunter expenditures, we used the interview data to estimate mean daily hunter expenditures for each regiontarget species combination. We calculated daily per-hunter expenditures within each region and for each hunter target species group by estimating hunter expenditures on lodging, food, and fuel. Based on answers to our lodging question, we classified hunters into one of three lodging categories. Hunters who reported staying at home or lodging with a friend or family member were assigned a lodging cost of \$O. Hunters who reported camping were assigned a lodging cost of $\$ 10$ per campsite per day (the median published price of a single public campsite in Nebraska; NGPC, 2018c), assuming each campsite held a maximum of two hunters. Finally, hunters who reported lodging in a hotel or similar lodging were assigned a lodging cost of $\$ 83$ in 2014, \$89 in 2015, and \$91 in 2016 (federal per-diem rates for Nebraska; U.S. General Services Administration, 2018), per two hunters per day, assuming double occupancy. For example, a two-hunter party lodging in a hotel would each be assigned one half of the estimated room cost. We similarly assigned hunters food costs according to lodging class. Parties who reported staying at home were assigned \$o, as we assumed expenditures on food did not reflect hunting-specific expenditures. Parties camping, lodging in a hotel, or staying with family or friends were assigned a per-hunter per-day food expenditure of $\$ 46$ in 2014, \$51 in 2015, and \$51 in 2016 (federal per-diem rates for Nebraska; U.S. General Services Administration, 2018).

We estimated fuel expenditures based on the assumption that each vehicle in the party was an 11-year-old (the national average) standard sized truck or SUV (most common vehicle observed; personal observation, Wszola), achieving $6.8 \mathrm{~km}$ per liter of fuel (U.S. Department of Energy, 2005). We assigned hunters a within-region fuel cost to 
account for the money they spent driving between sites and/or local towns and an outside-region fuel cost accounting for the potentially longer distance to and from hunter home ZIP codes. We assigned each hunter a standardized per-day within-region fuel expenditure based on the median round-trip travel cost for a vehicle to go to and from an equipped town (i.e., lodging and food) in any of the four study regions, to the centroid of the public access sites within the region. We divided the estimated within-region fuel expended for all vehicles in a party by the number of people in the party and calculated the perhunter within region fuel cost using the national average fuel cost from the month when the interview was conducted (U.S. Energy Information Administration, 2018). Using the statewide average party size of two hunters per vehicle, each hunter was assigned a $\$ 6$ per day within region fuel expenditure.

We calculated fuel expenditure outside the region for each hunter based on the estimated round-trip mileage from their home ZIP code to the site where they were interviewed. Using the package gmapsdistance (Melo, Rodriguez, \& Zarruk, 2018) in the R statistical environment (R Core Development Team, 2018), we calculated the driving distance from the centroid of each hunter's home ZIP code to the coordinates where they were interviewed. For parties where hunters originated in multiple ZIP codes, we used the average travel distance for all reported ZIP codes. The party was assigned a travel cost based on the cost of the fuel necessary to move all vehicles in the party to the site in the month the interview was conducted, which was then doubled to account for the return trip. We then estimated per-hunter fuel expenditure for outside-region travel by dividing the total estimated fuel cost for all vehicles in the party by the total number of hunters in the party.

Because we were interested in estimating the total per-day expenditures on public access hunting lands, it was necessary to express each hunter's outside-region fuel expenditure as a daily rate, even though fuel was likely purchased only on the day(s) the hunter entered and left the region. The per-hunter per-day expenditures for travel outside the region were therefore estimated as the per-hunter expenditure for round-trip travel to and from the hunter's home ZIP code divided by the number of days spent hunting within the study region. However, parties were interviewed at various stages of their trip, and hunting 
trip length is frequently contingent on hunter success (e.g., trips may end once bag limits are filled), which varies widely depending on hunter experience, game populations, and weather (Cooper, Pinheiro, Unsworth, \& Hilborn, 2002). Since stated expectations of trip length cannot be assumed to be reliable, we approximated trip length by recording the day within a trip that a party was interviewed (e.g., first day, second day, etc.). Assuming a party had an equal probability of being interviewed on any day within their trip, the proportion of interviews conducted on the first day afield is equal to the probability that any given day is the first or last day of a trip and the probability that hunters should be assigned their outside-region travel cost on a given day. Because the region and species pursued can also affect trip length, we calculated first-day-afield proportions for each region and hunter target species group, which we then multiplied by the per hunter fuel expenditure to calculate the per-hunter per-day cost of travel outside the region. Adding the $\$ 6$ per-day standardized within region fuel expenditure, we obtained a total per-hunter per-day fuel expenditure, which we then added to the daily lodging and food estimates to create per-hunter estimates of daily expenditures for each hunter target species group within each region.

\subsection{Analysis}

We estimated the number of unique hunter visits to each site on each day using Convolution Likelihood Ecological Abundance Regression (CLEAR; Gruber, Stuber, Wszola, \& Fontaine, 2018). CLEAR is an open population (i.e., individuals may enter or leave the system at any time) modeling method that integrates multiple population indices to produce a temporally-specific population estimate (e.g., daily or monthly estimated abundance). We used CLEAR to integrate bus route, camera car count, and interview data to predict how many vehicles were present at each study site on each study day, and the likelihood that a given trip represented a deer, duck, turkey, or upland bird hunting party. Briefly, CLEAR uses a likelihood based on the convolution of binomial and Poisson distributions to estimate temporallyspecific changes in an open population, allowing us to estimate unobserved values including immigration rate (i.e., the number of cars that arrived at a site per day) by integrating the estimated immigration 
rate over time. We used the interview data to estimate the probability that hunting parties visited another site before visiting the site at which they were observed to reduce the probability of double-counting hunters that moved between sites during the same day. We then multiplied the daily number of unique vehicle trips to each site by two, the average number of hunters per party for all target species, regions, and time periods, to create an estimate of unique hunter days per site per day (e.g., an estimate of two unique hunters visiting a site in a given day would be considered two hunter days). We then assigned each site a daily estimate of predicted hunter days and hunter expenditures by multiplying the per-hunter per-day expenditures estimate by the number of predicted hunter days per site per day for each land ownership type, target species, and region.

We assessed the effects of region and land ownership on hunter use days per hectare per month by fitting one linear mixed model with random effects of study year and fixed effects of region, land ownership, and study month in package lme4 (Bates et al., 2018). To minimize confounding effects of weekends and holidays, which are popular days for hunting, we summed the total predicted hunter trips per site per month and divided it by the area of the site open to the public to produce an index of hunter use per hectare per month. We log-transformed estimates of hunter use per hectare per month to guarantee positive back-transformed model predictions. We assessed model fit by calculating marginal (without random effects) and conditional (with random effects) $\mathrm{R}^{2}$ values using package MuMIn (Bartoń, 2018; Nakagawa \& Schielzeth, 2012). We present estimated parameter means and 95\% credible intervals for each model based on 10,000 draws from the joint posterior distribution, estimated using package arm with default priors (Gelman et al., 2018).

We additionally fit one linear mixed-effects model assessing sources of variation in hunter expenditures at time of interview in lme 4 as above. We log-transformed hunter expenditures to guarantee positivity of back-transformed results and included a random effect of study year and fixed effects of study region, month, target species, and hunter age and travel distance (mean-centered and scaled to 1 standard deviation). We assessed model fit using $\mathrm{R}^{2}$ values and estimated fixed effects using 10000 draws from the joint posterior distribution, simulated using package arm as described above. 


\section{Results}

We collected 10,175,390 time-lapse images, conducted 85,809 bus route count surveys, and collected interviews representing 2,806 deer, duck, turkey, and upland hunter days in 1,559 total interviews across 4 regions during the 2014-2016 hunting seasons. Availability of public access sites and hectares of public access differed by region as did predominate target species, hunter expenditures, and hunter home population density (Tables 1-3). Mean ( \pm standard error) hunter age was $43 \pm 0$ years and $62 \%$ of reported ZIP codes were from Nebraska (Table 1). The mean reported travel distance was $460 \pm 11 \mathrm{~km}$, and mean expected round trip fuel expenditures from home ZIP code to interview location and back was \$37 \pm \$1 (Table 2). The mean expected food expenditure was $\$ 24 \pm \$ 0$ per day, and the mean expected lodging expenditure was $\$ 16 \pm \$ 0$ per day. The mean population density of reported home zip codes was $433 \pm 12$ residents per square $\mathrm{km}$ of land area (Table 1).

Table 1 Number of hunter days sampled, percent of interviews conducted on the first day of a hunting trip, percent of reported ZIP codes that originated in Nebraska, mean age (years \pm se), harvest success, and home population density (people per sq km of land area) of deer, duck, turkey, and upland bird hunters interviewed on public access properties across Nebraska from 2014 to 2017.

\begin{tabular}{|c|c|c|c|c|c|c|c|}
\hline Region & $\begin{array}{l}\text { Target } \\
\text { Species }\end{array}$ & $\begin{array}{c}\text { Hunters } \\
\text { Interviewed }\end{array}$ & $\begin{array}{l}\text { \% Interviews } \\
\text { conducted on } \\
\text { the first day of } \\
\text { the hunting trip }\end{array}$ & $\begin{array}{l}\% N E \\
\text { residents }\end{array}$ & $\begin{array}{l}\text { Mean } \\
\text { age }\end{array}$ & $\begin{array}{c}\text { \% Harvest } \\
\text { Success }\end{array}$ & $\begin{array}{c}\text { Population } \\
\text { density }\end{array}$ \\
\hline \multirow[t]{3}{*}{ North Panhandle } & Deer & 332 & $20 \%$ & $43 \%$ & $40 \pm 1$ & $23 \%$ & $212 \pm 30$ \\
\hline & Turkey & 9 & $89 \%$ & $78 \%$ & $42 \pm 7$ & $22 \%$ & $46 \pm 24$ \\
\hline & Upland & 10 & $100 \%$ & $80 \%$ & $26 \pm 3$ & $30 \%$ & $230 \pm 138$ \\
\hline \multirow[t]{3}{*}{ Rainwater Basin } & Deer & 15 & $73 \%$ & $73 \%$ & $34 \pm 4$ & $\mathrm{O} \%$ & $124 \pm 88$ \\
\hline & Ducks & 276 & $84 \%$ & $89 \%$ & $34 \pm 1$ & $76 \%$ & $413 \pm 38$ \\
\hline & Upland & 379 & $83 \%$ & $83 \%$ & $44 \pm 1$ & $44 \%$ & $445 \pm 32$ \\
\hline \multirow[t]{4}{*}{ Southeast } & Deer & 287 & $74 \%$ & $78 \%$ & $40 \pm 1$ & $14 \%$ & $529 \pm 37$ \\
\hline & Ducks & 4 & $100 \%$ & $100 \%$ & $34 \pm 6$ & $25 \%$ & $722 \pm 185$ \\
\hline & Turkey & 14 & $100 \%$ & $100 \%$ & $51 \pm 5$ & $29 \%$ & $1007 \pm 120$ \\
\hline & Upland & 448 & $92 \%$ & $83 \%$ & $46 \pm 1$ & $45 \%$ & $522 \pm 28$ \\
\hline \multirow[t]{4}{*}{ Southwest } & Deer & 270 & $20 \%$ & $47 \%$ & $43 \pm 1$ & $25 \%$ & $397 \pm 36$ \\
\hline & Ducks & 38 & $55 \%$ & $59 \%$ & $39 \pm 2$ & $50 \%$ & $309 \pm 106$ \\
\hline & Turkey & 13 & $46 \%$ & $46 \%$ & $48 \pm 3$ & $15 \%$ & $402 \pm 156$ \\
\hline & Upland & 711 & $38 \%$ & $32 \%$ & $47 \pm 1$ & $39 \%$ & $466 \pm 27$ \\
\hline
\end{tabular}


Table 2 Mean estimated daily food and lodging expenditures( $\$ \pm \mathrm{se})$, round-trip fuel costs ( $\$ \pm$ se), mean travel distance $(\mathrm{km} \pm \mathrm{se})$ mean trip length at time of interview (days $\pm \mathrm{se})$, and mode crowdedness rating (mode and $\%$ mode) of deer, duck, turkey, and upland bird hunters interviewed at public access hunting sites in Nebraska from 2014 to 2017.

\begin{tabular}{|c|c|c|c|c|c|c|c|}
\hline Region & $\begin{array}{l}\text { Target } \\
\text { Species }\end{array}$ & $\begin{array}{c}\text { Mean daily } \\
\text { per-hunter } \\
\text { food } \\
\text { expenditures }\end{array}$ & $\begin{array}{l}\text { Mean daily } \\
\text { per-hunter } \\
\text { lodging } \\
\text { expenditures }\end{array}$ & $\begin{array}{c}\text { Mean } \\
\text { per-hunter } \\
\text { road trip } \\
\text { fuel cost }\end{array}$ & $\begin{array}{c}\text { Mean } \\
\text { travel } \\
\text { distance }\end{array}$ & $\begin{array}{c}\text { Mean } \\
\text { trip } \\
\text { Length }\end{array}$ & $\begin{array}{c}\text { Mode } \\
\text { crowdedness } \\
\text { rating }\end{array}$ \\
\hline \multirow[t]{3}{*}{ North Panhandle } & Deer & $41 \pm 1$ & $29 \pm 1$ & $77 \pm 3$ & $1028 \pm 38$ & $3 \pm 0$ & $5(40 \%)$ \\
\hline & Turkey & $10 \pm 7$ & $2 \pm 1$ & $36 \pm 21$ & $350 \pm 231$ & $1 \pm 0$ & $5(67 \%)$ \\
\hline & Upland & $9 \pm 6$ & $8 \pm 6$ & $22 \pm 6$ & $268 \pm 94$ & $1 \pm 0$ & $5(100 \%)$ \\
\hline \multirow[t]{3}{*}{ Rainwater Basin } & Deer & $12 \pm 5$ & $\mathrm{O} \pm \mathrm{O}$ & $11 \pm 3$ & $231 \pm 77$ & $2 \pm 0$ & $5(40 \%)$ \\
\hline & Ducks & $10 \pm 1$ & $4 \pm 1$ & $19 \pm 2$ & $232 \pm 21$ & $1 \pm 0$ & $5(47 \%)$ \\
\hline & Upland & $9 \pm 1$ & $3 \pm 1$ & $22 \pm 2$ & $259 \pm 20$ & $1 \pm 0$ & $5(71 \%)$ \\
\hline \multirow[t]{4}{*}{ Southeast } & Deer & $17 \pm 1$ & $12 \pm 1$ & $33 \pm 3$ & $339 \pm 31$ & $2 \pm 0$ & $5(43 \%)$ \\
\hline & Ducks & $\mathrm{O} \pm \mathrm{O}$ & $\mathrm{O} \pm \mathrm{O}$ & $8 \pm 3$ & $122 \pm 7$ & $1 \pm 0$ & $5(75 \%)$ \\
\hline & Turkey & $\mathrm{O} \pm \mathrm{O}$ & $\mathrm{O} \pm \mathrm{O}$ & $9 \pm 1$ & $111 \pm 4$ & $1 \pm 0$ & $3(50 \%)$ \\
\hline & Upland & $7 \pm 1$ & $6 \pm 1$ & $18 \pm 1$ & $243 \pm 17$ & $1 \pm 0$ & $5(50 \%)$ \\
\hline \multirow[t]{4}{*}{ Southwest } & Deer & $42 \pm 1$ & $16 \pm 1$ & $47 \pm 3$ & $523 \pm 30$ & $3 \pm 0$ & $5(29 \%)$ \\
\hline & Ducks & $25 \pm 4$ & $6 \pm 3$ & $24 \pm 5$ & $258 \pm 51$ & $2 \pm 0$ & $5(73 \%)$ \\
\hline & Turkey & $25 \pm 7$ & $3 \pm 1$ & $12 \pm 9$ & $245 \pm 52$ & $2 \pm 0$ & $5(88 \%)$ \\
\hline & Upland & $37 \pm 1$ & $29 \pm 1$ & $45 \pm 2$ & $586 \pm 21$ & $2 \pm 0$ & $5(71 \%)$ \\
\hline
\end{tabular}

Table 3 Area surveyed, predicted total hunter days, and predicted total hunter expenditures of hunters interviewed at public access hunting sites in Nebraska from 2014 to 2017 varied across regions and study years.

\begin{tabular}{lccccc} 
Region & $\begin{array}{c}\text { Study } \\
\text { Year }\end{array}$ & $\begin{array}{c}\text { Public land } \\
\text { studied (ha) }\end{array}$ & $\begin{array}{c}\text { Open fields } \\
\text { land area } \\
\text { studied (ha) }\end{array}$ & $\begin{array}{c}\text { Predicted } \\
\text { hunter } \\
\text { days }\end{array}$ & $\begin{array}{c}\text { Predicted } \\
\text { hunter } \\
\text { expenditures, (\$) }\end{array}$ \\
\hline North Panhandle & 2014 & 5523 & 5831 & 1101 & 95,134 \\
& 2015 & 5522 & 6099 & 1434 & 124,083 \\
Rainwater Basin & 2016 & 5522 & 5729 & 1021 & 921,758 \\
& 2014 & 5818 & 106 & 4480 & 157,822 \\
Southeast & 2015 & 5818 & 106 & 1569 & 56,193 \\
& 2016 & 5818 & 66 & 983 & 35,016 \\
Southwest & 2014 & 2255 & 3861 & 2582 & 130,947 \\
& 2015 & 2255 & 3526 & 3616 & 170,940 \\
& 2016 & 2226 & 3485 & 3035 & 147,256 \\
& 2014 & 5155 & 3397 & 1842 & 142,890 \\
& 2015 & 5143 & 2862 & 3960 & 301,315 \\
& 2016 & 5144 & 3418 & 2381 & 178,971 \\
\hline
\end{tabular}




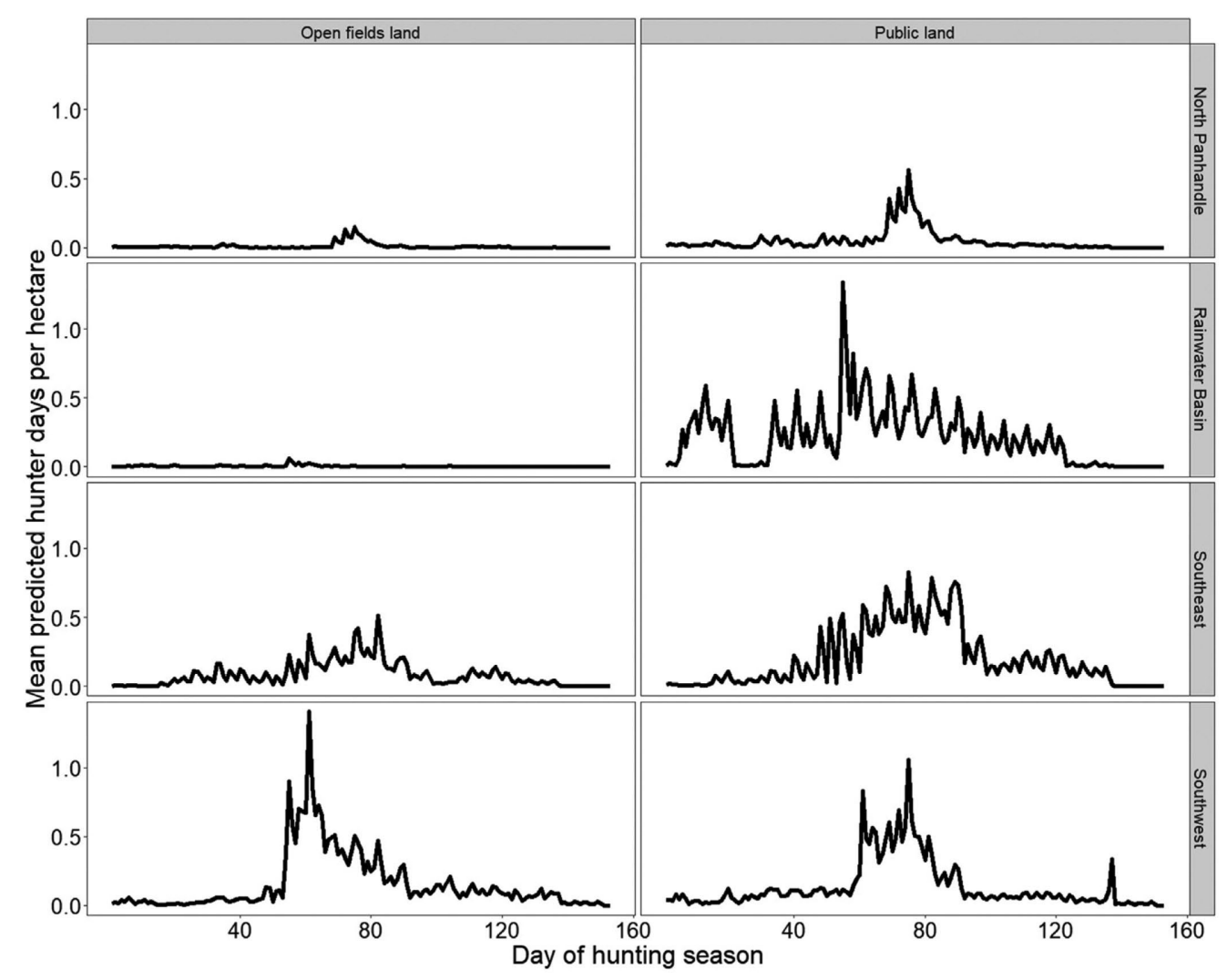

Fig. 3. The number of hunter days per hectare per day (averaged from 2014 to 2016) peaked in the North Panhandle, Southeast, and Southwest during the upland bird and rifle deer seasons. Hunter use was also relatively high in the Rainwater Basin during the upland bird season, and additionally during the early teal and regular waterfowl seasons. Hunter use was higher on traditional public lands than on open fields for all regions except the Southwest, where upland birds are relatively abundant.

\subsection{Hunter use}

Hunter use of public access sites generally peaked around the opening of the upland bird and rifle deer seasons, except in the Rainwater Basin region, which exhibited a pulsatile pattern (Fig. 3). The magnitude of predicted hunter use differed by region and exhibited considerable inter-annual variation, with the Southeast region experiencing the greatest mean use per year (3078 \pm 299 hunter days per year), and the North Panhandle the least (1185 \pm 127 hunter days per year; Table 3). Per-hectare use was generally greater on traditional public 
Table 4 Parameter means $(\beta)$ and 95\% credible intervals (CI) for the model relating hunter days per hectare per month to site ownership and region. Credible intervals that do not overlap o are highlighted in bold.

\begin{tabular}{lrr} 
Parameter & $\beta$ & $95 \%$ CI \\
\hline Intercept (Open fields land, North Panhandle, September) & -6.27 & $-6.54,-6.01$ \\
Owner: public land & 1.04 & $0.97,1.11$ \\
Region: Rainwater Basin & 1.39 & $1.30,1.49$ \\
Region: Southeast & 2.08 & $1.99,2.16$ \\
Region: Southwest & 2.04 & $1.95,2.12$ \\
Month: October & 1.25 & $1.16,1.34$ \\
Month: November & 2.20 & $2.11,2.30$ \\
Month: December & 0.90 & $0.80,0.99$ \\
Month: January & -1.21 & $-1.30,-1.12$ \\
\hline
\end{tabular}

lands than on open fields sites (Table 4). Predicted per-hectare use was greatest among public lands in the Southeast in November (0.39 hunter days per hectare per month) and least on open fields sites in the North Panhandle in January (0.001 hunter days per hectare per month). The model explaining variation in hunter days per hectare per month had a marginal $\mathrm{R}^{2}$ of 0.67 , and a conditional $\mathrm{R}^{2}$ of 0.68 .

\subsection{Hunter expenditures}

Individual hunter expenditures were predicted to be greatest in the Southwest, intermediate in the North Panhandle, and smallest in the Southeast and Rainwater Basin (Table 5, Fig. 4). Southwest deer hunters were predicted to spend the most per trip (\$145 per hunter per trip at mean age and travel distance) and Southeast turkey hunters were predicted to spend the least ( $\$ 17$ per hunter per trip at mean age and travel distance). Hunter expenditures were positively associated with hunter age and distance traveled, and differed by species targeted, with duck and turkey hunters predicted to spend the least, and deer and upland bird hunters predicted to spend the most. The per-hunter expenditure model had a marginal and conditional $\mathrm{R}^{2}$ value of 0.59 . Total hunter expenditures differed by land ownership type, region, and year (Tables 2 and 3, Fig. 4), with the greatest expenditure per region per year predicted on the Southwest study sites ( $\$ 209,181 \pm \$ 47,983$ ), and the smallest on the Rainwater Basin study sites $(\$ 83,105 \pm \$ 46,968)$. 
Table 5 Parameter means $(\beta)$ and 95\% credible intervals (CI) for the model relating total per-hunter expenditures on a hunting trip at the time of interview to Region, target species, age, and distance traveled. Credible intervals that do not overlap o are highlighted in bold.

\begin{tabular}{lrr} 
Parameter & $\beta$ & $95 \%$ CI \\
\hline Intercept (Deer, North Panhandle, September) & 4.44 & $4.19,4.68$ \\
Region: Rainwater Basin & -0.48 & $-0.65,-0.31$ \\
Region: Southeast & -0.65 & $-0.80,-0.50$ \\
Region: Southwest & 0.53 & $0.39,0.68$ \\
Target Species: Ducks & -0.39 & $-0.56,-0.22$ \\
Target Species: Turkey & -0.93 & $-1.28,-0.59$ \\
Target Species: Upland & -0.46 & $-0.56,-0.35$ \\
Age & 0.13 & $0.10,0.17$ \\
Distance traveled & 0.84 & $0.79,0.88$ \\
Month: October & 0.03 & $-0.18,0.25$ \\
Month: November & 0.20 & $-0.02,0.41$ \\
Month: December & 0.16 & $-0.07,0.40$ \\
Month: January & 0.17 & $-0.08,0.42$ \\
\hline
\end{tabular}

\section{Discussion}

Public land managers tasked with optimizing limited public access funding for recreational and economic objectives are increasingly turning to open fields programs with the potential to serve urbanizing hunter populations (Cooper et al., 2002b; Knoche \& Lupi, 2007; Marshall, 2018; Rudzitis, 1999). In Nebraska, however, open fields lands generally provided lower returns in hunter use and expenditures than did traditional public lands, except in the Southwest study region. Hunter use was greatest in the Southeast region near the two cities of Lincoln and Omaha, but hunter expenditures were greatest in the Southwest region, a well-advertised upland bird and deer destination. The varying performance of open fields programs in terms of use and expenditures suggests that the different benefits provided by open fields and traditional public lands may require policymakers and land managers to make tradeoffs between recreational and economic objectives. 


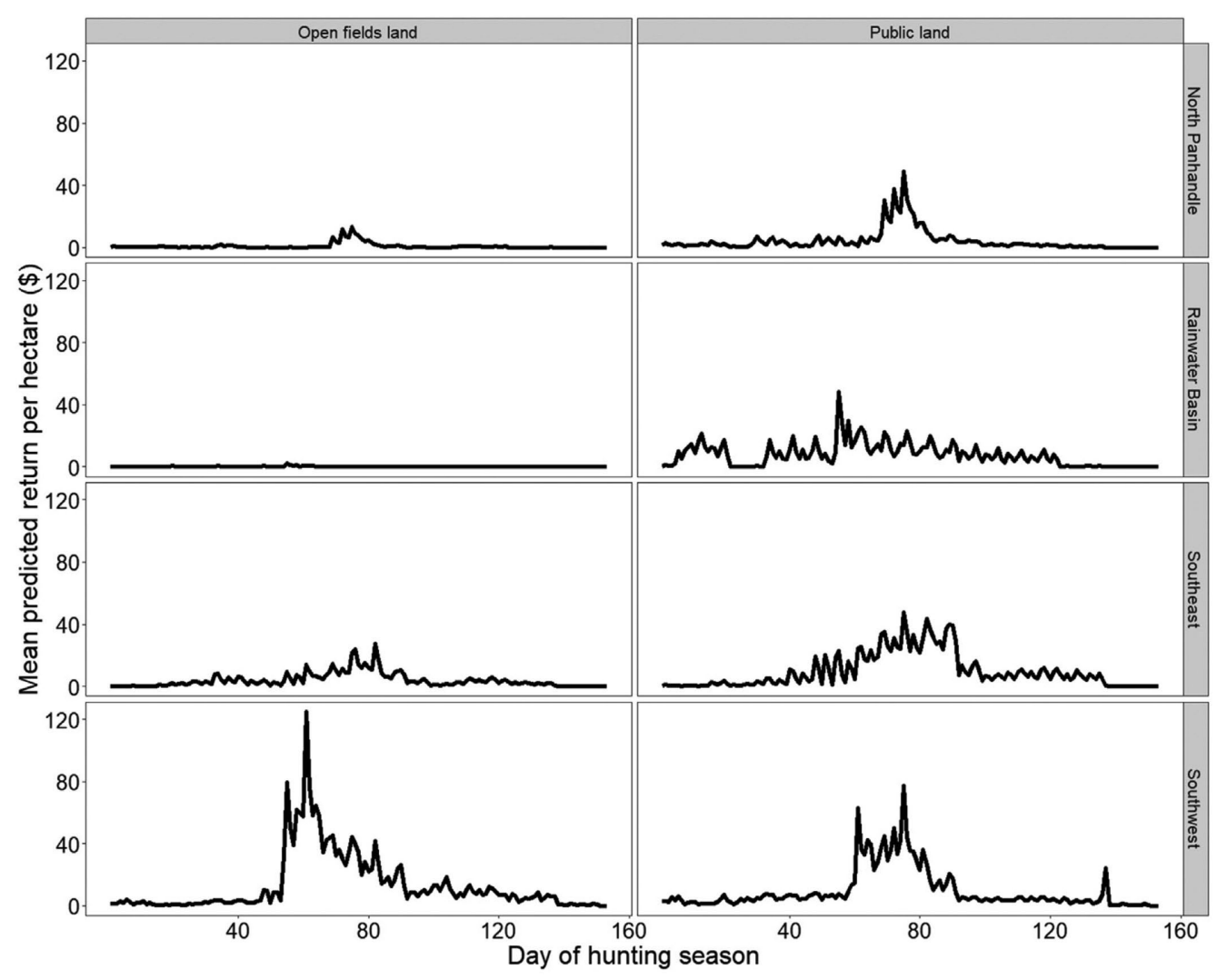

Fig. 4. Estimated hunter expenditures per hectare per day (averaged from 2014 to 2016) peaked in all regions during the rifle deer and upland bird seasons. Average hunter expenditures per hectare per day were greatest on open fields land in the Southwest Region. Open fields lands in the North Panhandle and Rainwater Basin regions provided little hunter expenditures due to low use.

\subsection{Hunter use and site decisions}

Our finding that open fields properties generally experienced lower use per hectare than did traditional public lands makes sense in light of previous investigations into hunter demand for public access hunting lands. Sportspersons often consider the financial and opportunity costs associated with different sites when making site selection decisions (Balkan \& Kahn, 1988; Montgomery \& Blalock, 2010; Offenbach \& Goodwin, 1994). Hunters deciding how to allocate limited time and money may therefore perceive visiting annually-enrolled open fields sites as a risky use of scarce recreational time because open fields sites represent an unknown quantity. Additionally, public land users form attachments to public lands and may derive satisfaction 
from revisiting a site where they have established memories and traditions (Eisenhauer, Krannich, \& Blahna, 2000; Stedman, Bhandari, Luloff, Diefenbach, \& Finley, 2008). Hunters who prefer to visit a site repeatedly over years may therefore prefer to spend time at sites that they can predict to be accessible in succeeding years, creating challenges for land managers seeking to establish sites that will receive high hunter use.

Although traditional public lands received more use than did open fields lands overall, open fields properties that provided a specialized and well-publicized hunting opportunity received relatively high use. Open fields properties in the Southwest region experienced hunter use rates similar to those of traditional public lands, in contrast to the other study regions. Greater hunter use of open fields sites in the Southwest study region likely reflects strategic management and communication decisions made by the state natural resources agency. Sites in the Southwest are prioritized for pheasant habitat management and NGPC actively advertises the Southwest as a pheasant hunting destination (Lucas, 2013; NGPC, 2015; NGPC, 2016; NGPC, 2017a; NGPC, 2017d). The greater open fields use in the Southwest, compared to open fields sites in other regions, may demonstrate that open fields programs can draw use and spark hunter expenditures when they provide well-managed and well-advertised hunting opportunities for sought-after game species. This interpretation is bolstered by the spike in use the Southwest experienced in 2015. The drought of 2012-2013 drastically reduced pheasant abundance and pheasant hunter participation during those years (Jorgensen, Powell, Lusk, Bishop, \& Fontaine, 2014). Pheasant populations rebounded beginning in 2014, and especially in 2015, a fact that was communicated by NGPC (NGPC, 2015; Stuber, Gruber, \& Fontaine, 2017). The sharp spike in hunter use during the 2015 hunting season therefore likely results from information about recovering pheasant populations disseminating through the hunter community, either from official sources or through word-ofmouth from those hunters who did hunt during the 2014 season. Our results therefore support the hypothesis (e.g., Hunt \& Ditton, 1997; Larson, Stedman, Decker, Siemer, \& Baumer, 2014) that a public access site's social and ecological environment influences the value of the site to hunters, agencies, and rural communities. 


\subsection{Hunter expenditures}

Total hunter expenditures estimated for study sites largely reflected patterns of use among land ownership types and regions, but differences in reported hunter travel behavior also contributed to differences in total estimated expenditures (Tables 1-5). Individual expenditures tended to increase with hunter age (Table 5), but the greater expenditures in western Nebraska were largely reflective of travel distance from metropolitan centers, and not necessarily intrinsic differences in the demographics of public access hunters among regions (Tables 1 and 2). National trends towards urbanization (Homer et al., 2015), including among hunters (Stedman, Bhandari, Luloff, Diefenbach, \& Finley, 2008), have resulted in hunters traveling farther to fulfill their recreational interests and spending more on food, fuel, and lodging (U.S. Fish and Wildlife Service, 2018).

The willingness of hunters to spend more time and money to hunt public access properties in the Southwest and North Panhandle regions suggests hunters may perceive these sparsely populated, ecologically unique regions as ‘destination' hunting locations worthy of additional investment, a finding in line with previous studies of hunter travel cost decisions (Balkan \& Kahn, 1988; Komppula \& Gartner, 2013). So what makes western Nebraska a destination? Do the regional differences in expenditures simply reflect the demographic distribution of hunters (i.e., most users of public access land in sparsely populated regions will tend to come from somewhere else), or is something drawing hunters west that could provide insight into how to increase hunter use and expenditures in other areas?

For deer hunters, the target species group with the highest percapita expenditures (Tables 2 and 3, Table 5), western Nebraska offers the opportunity to hunt mule deer. Nebraska is among the easternmost U.S. states where mule deer populations exist in harvestable numbers, offering a "budget" hunting opportunity to hunters across the Midwest (Flader, 1983; Western Association of Fish and Wildlife Agencies Mule Deer Working Group, 2016). Indeed, deer hunters in the North Panhandle reported among the longest travel distances and trip lengths of any hunters interviews, which explained their high per-hunter expenditures (Tables 2 and 3, Table 5). Nebraska has considerably fewer acres of public access available for mule deer hunting 
than western states, but by offering mule deer hunting opportunities with lower travel costs for Eastern and Midwestern hunters, Nebraska public access sites may appeal to hunters unwilling or unable to spend additional money for western big game opportunities. Hunters' willingness to invest time and money in a unique outdoor experience aligns with previous findings (Bryan, 1977; Rosenberger, White, Kline, \& Cvitanovich, 2017; Whitten \& Bennett, 2002) and highlights the value of providing public access in ecologically rich rural regions for non-local hunters less likely to have private land access. The distribution of mule deer limits the potential for growing access in Nebraska at large. However, given the low per-hectare use rates in the North Panhandle (Table 3, Fig. 3), the region that provided the best access to mule deer, adding new sites may not substantially increase total hunter use or expenditures. Indeed, the limited use of open field sites by deer hunters throughout Nebraska, but especially in the North Panhandle, suggests that the best avenue toward increasing hunter expenditures on deer hunting in rural communities may be to foster increased participation among deer hunters on the sites that already exist.

Like deer hunters in the North Panhandle, pheasant hunters in the Southwest region reported behaviors indicative of relatively high precipitate expenditures, suggesting that even moderate increases in participation could produce gains in hunter expenditures for rural areas. Given that per-hectare use rates in the Southwest region were somewhat lower than in the more urban Southeast region (Table 3, Fig. 3), we might conclude that there is sufficient access in the Southwest region to support additional pheasant hunter effort. However, idiosyncrasies of pheasant hunting suggest access for pheasant hunting in the Southwest region may be limiting. Pheasant hunting participation and pheasant harvest have a strong initial peak (Fig. 3) in Nebraska and elsewhere (Errington \& Gewertz, 2015). Although pheasant hunters perceive public access sites as not crowded (Table 2), an indication that hunters at any one time found sufficient access, concentrated use early in the season can reduce participation later if hunters believe opportunities for future harvest are reduced (Siemer, Decker, \& Stedman, 2016). The relatively high use of open fields sites in the Southwest, coupled with the temporal variation in use suggests that adding open fields access in areas with the potential for crowding at 
certain times of the season may draw hunters back into the field in the under-used late season by providing the expectation of harvesting more target animals.

\section{Conclusion}

Disconnects between the social and ecological drivers of hunter use and expenditures drove disconnects in the use and expenditure benefits of open fields and traditional public lands. Overall hunter use was the greatest close to metropolitan areas, despite the unique upland bird and western big game opportunities offered by the rural western Nebraska study regions. However, the Southwest study region, which offers the state's most abundant pheasant populations, experienced a large surge of use at the start of the pheasant season that corresponded with a peak in expenditures by urban visitors. Our results agree with previous evidence (Karns, Bruskotter, \& Gates, 2015; Knoche \& Lupi, 2013; Korpela, Borodulin, Neuvonen, Paronen, \& Tyrväinen, 2014) that when public lands are easily accessible from urban areas or provide a unique resource such as pheasants to visitors, the benefits of open fields programs to residents and visitors to rural communities can be considerable. One potential caution when interpreting our results is that our methods create the potential for avidity bias (Ditton \& Hunt, 2008). Because avid hunters spend more time in the field, it is possible that avid hunters are over-represented in our sample. However, the results should still be applicable to the demographics and experience of the hunting public in the field on any given day because our analysis focused on use and expenditures, not individual hunters. Future work should furthermore consider how an affinity for or familiarity with specific sites affects hunter use and expenditure decisions, as well as the subjective hunting experience. Additionally, further work on dimensions of recreational value beyond use and expenditures (e.g., hunter satisfaction, the utility of properties providing multiple types of opportunities) is needed to facilitate holistic comparisons of public access land recreational value.

As the hunting population ages and urbanizes, the social ties that traditionally facilitated hunting access on private lands are breaking down, creating a need for a new kind of public access (Stedman, 
Bhandari, Luloff, Diefenbach, \& Finley, 2008). Our results suggest that public hunting access objectives may be best reached through diversified investment in traditional public and open fields lands across regions that differ in the opportunities they provide. Rural areas with abundant or unique game populations may serve well as destination locations worthy of rural infrastructure development, while easily accessible, affordable, and family-friendly hunting opportunities near urban areas will serve urban residents with limited time and money. Though traditional public lands will doubtless continue to provide essential hunting opportunities in Nebraska and beyond, our results demonstrate that strategic implementation of open fields programs, coupled with strategic communication, can substantially supplement traditional public hunting opportunities and spur hunter expenditures in rural communities.

Acknowledgments Funding for this project was received from Federal Aid in Wildlife Restoration project W-115-R, administered by the Nebraska Game and Parks Commission. Author CJC was supported by Hatch funds through the Agricultural Research Division at the University of Nebraska- Lincoln and from Federal Aid in Wildlife Restoration project W-12O-T-1, administered by the Nebraska Game and Parks Commission. We thank M. Winkler, J. Laux, J. Lusk, and K. Decker for conversations that inspired this work, the many hunters and hunter survey technicians who generated the hunter survey data, and three anonymous reviewers and the subject editor whose feedback greatly improved the manuscript. We finally thank PWB and LWB for insights on upland bird ecology. The authors declare there are no competing interests. Full code and deidentified data are available from https://osf.io/ zej4x/?view only $=200 c 4$ fae1ffe 4 c $89 b 48432 e 8 d d 43 c 599$

\section{References}

Adamowicz, W., Jennings, S., \& Coyne, A. (1990). A sequential choice model of recreation behavior. Western Journal of Agricultural Economics, 15(1), 91-99.

Adams, R. M., Bergland, O., Musser, W. N., Johnson, S. L., \& Musser, L. M. (1989). User fees andequity issues in public hunting expenditures: The case of ringnecked pheasant in Oregon. Land Economics, 65(4), 376-385.

Arnberger, A., Ebenberger, M., Schneider, I. E., Cottrell, S., Schlueter, A. C., von Ruschkowski, E., et al. (2018). Visitor preferences for visual changes in bark beetleimpacted forest recreation settings in the United States and Germany. Environmental Management, 61, 209-223.

Arnett, E. B., \& Southwick, R. (2015). Economic and social benefits of hunting in North America. International Journal of Environmental Studies, 72(5), 734-745. 
Balkan, E., \& Kahn, J. R. (1988). The value of changes in deer hunting quality: A travel costapproach. Applied Economics, 20(4), 533-539.

Bartoń, K. (2018). Package ‘MuMIn’. ftp://155.232.191.229/cran/web/packages/ MuMIn/MuMIn.pdf.

Bates, D., Maechler, M., Bolker, B., Walker, S., Christensen, R. H. B., Singmann, H., et al. (2018). lme4: linear mixed-effects models using 'Eigen' and $\mathrm{S}_{4}$. https:// cran.r-project.org/web/packages/lme4/index.html.

Beardmore, B., Haider, W., Hunt, L. M., \& Arlinghaus, R. (2011). The importance of trip context for determining primary angler motivations: Are more specialized anglers more catch-oriented than previously believed? North American Journal of Fisheries Management, 31, 861-879.

Beardmore, B., Haider, W., Hunt, L. M., \& Arlinghaus, R. (2013). Evaluating the ability of specialization indicators to explain fishing preferences? Leisure Sciences, 35(3), 273-292.

Beardmore, B., Hunt, L. M., Haider, W., Dorow, M., \& Arlinghuas, R. (2015). Effectively managing angler satisfaction in recreational fisheries requires understanding the fish species and the anglers. Canadian Journal of Fisheries and Aquatic Sciences, 72(4), 500-513.

Bhandari, P., Stedman, R. C., Luloff, A. E., Finley, J. C., \& Diefenbach, D. R. (2006). Effort versus motivation: Factors affecting antlered and antlerless deer harvest success in Pennsylvania. Human Dimensions of Wildlife, 11(6), 423-436.

Bilgic, A., Florkowski, W. J., Yoder, J., \& Schreiner, D. F. (2008). Estimating fishing and hunting leisure spending shares in the United States. Tourism Management, 29(4), 771-782.

Bronner, S. J. (2004). "This is why we hunt”: Social-psychological meanings of the traditions and rituals of deer camp. Western Folklore, 63(1-2), 11-50.

Bryan, H. (1977). Leisure value systems and recreational specialization: The case of trout fishermen. Journal of Leisure Research, 9(3), 174-187.

Burger, J. (2000). A Comparison of on-site hunters, sportsmen and the general public about recreational rates and future land use preferences for the Savannah River Site. Journal of Environmental Planning and Management, 43(2), 221-223.

Burger, L. W., Miller, D. A., \& Southwick, R. I. (1999). Economic impact of northern bobwhite hunting in the Southeastern United States. Wildlife Society Bulletin, 27(4), 1010-1018.

Coker, R. H., Coker, M. S., Bartlett, L., Murphy, C. J., Priebe, K., Shriver, T. C., et al. (2018). The energy requirements and metabolic benefits of wilderness hunting in Alaska. Physiological Reports, 6(21), e13925.

Cooper, A. B., Pinheiro, J. C., Unsworth, J. W., \& Hilborn, R. (2002). Predicting hunter success rates from elk and hunter abundance, season structure, and habitat. Journal of Wildlife Management, 30(4), 1068-1077.

Cooper, A. B., Stewart, F., Unsworth, J. W., Kuck, L., \& McArthur, T. J. (2002b). Incorporating economic impacts into wildlife management. Wildlife Society Bulletin, 30(2), 565-574. 
Devers, P. K., Roberts, A. J., Knoche, S., Padding, P. I., \& Raftovich, R. (2017). Incorporating human dimensions objectives into waterfowl habitat planning and delivery. Wildlife Society Bulletin, 41(3), 405-415.

Ditton, R. B., \& Hunt, K. M. (2008). Combining creel intercept and mail survey methods to understand the human dimensions of local freshwater fisheries. Fisheries Management and Ecology, 8(4-5), 295-301.

Eisenhauer, B. W., Krannich, R. S., \& Blahna, D. J. (2000). Attachments to special places on public lands: An analysis of activities, reason for attachments, and community connections. Society \& Natural Resources, 13(5), 421-441.

Enck, J. W., Swift, B. L., \& Decker, D. J. (1993). Reasons for decline in duck hunting: Insights from New York. Wildlife Society Bulletin, 21(1), 10-21.

Errington, F., \& Gewertz, D. (2015). Pheasant capitalism: Auditing South Dakota's state bird. American Ethnologist, 42(3), 399-414.

Flader, S. (1983). The great lakes forest: An environmental and social history. University of Minnesota Press.

Gelman, A., Su, Y., Yajima, M., Hill, J., Pittau, M. G., Kerman, J., et al. (2018). arm: data analysis using regression and multilevel/hierarchical models. https:// cran.r-project.org/web/packages/arm/index.html

Grado, S. C., Hunt, K. M., Hutt, C. P., Santos, X. T., \& Kaminski, R. M. (2011). Economic impacts of waterfowl hunting in Mississippi derived from a statebased mail survey. Human Dimensions of Wildlife, 16(2), 100-113.

Greenberg, S., \& Godin, T. (2015). A tool supporting the extraction of angling effort data from remote camera images. Fisheries Magazine, 40(6), 276-287.

Gruber, L. F., Stuber, E. F., Wszola, L. S., \& Fontaine, J. J. (2018). Estimating the use of public lands: integrated modeling of open populations with Convolution Likelihood Ecological Abundance Regression. Bayesian Analysis. https://doi. org/10.1214/19-BA1152.

Hamzah, A., \& Khalifah, Z. (2012). Community capacity building for sustainable tourism development: Experience from Miso Walai homestay. Community Capacity Building, 2, 1-10.

Harmon, B. S. (2017). Recreational angler site choice and behavior within midwestern reservoirs. Thesis. University of Nebraska-Lincoln.

Hayslette, S. E., Armstrong, J. B., \& Mirarchi, R. E. (2001). Mourning dove hunting in Alabama: Motivations, satisfactions, and sociocultural influences. Human Dimensions of Wildlife, 6(2), 81-95.

Heberlein, T. A., Ericsson, G., \& Wollscheid, K. U. (2002). Correlates of hunting participation in Europe and North America. Zeitschrift für Jagdwissenschaft, 48(1), 320-326.

Heberlein, T. A., Serup, B., \& Ericsson, G. (2008). Female hunting participation in North America and europe. Human Dimensions of Wildlife, 13(6), 443-458.

Helland, J. (2006). Walk-in hunting programs in other states. Information Brief, Minnesota House of Representatives.

Hernández, F., Brennan, L. A., DeMaso, S. J., Sands, J. P., \& Wester, D. B. (2012). On reversing the northern bobwhite population decline: 20 years later. Wildlife Society Bulletin, 37(1), 177-188. 
Hiller, T. L., Taylor, J. S., Lusk, J. J., Powell, L. A., \& Tyre, A. J. (2015). Evidence that the Conservation Reserve Program slowed population declines of pheasants on a changing landscape in Nebraska, USA. Wildlife Society Bulletin, 39(3), 529-535.

Holmes, T. P., Bowker, J. M., Englin, J., Hjerpe, E., Loomis, J. B., Phillips, S., et al. (2015). A synthesis of the economic values of wilderness. Journal of Forestry, 114(3), 320-328.

Holsman, R., Beardmore, B., Bradshaw, L., \& Petchenik, J. (2018). A survey of applicant preferences for black bear hunting opportunities in Wisconsin. Prepared by: Bureau of Environmental Analysis and Sustainability. Submitted to Bureau of Wildlife Management.

Homer, C., Dewitz, J., Yang, L., Jin, S., Danielson, P., Xian, G., et al. (2015). Completion of the 2011 national land cover dataset for the conterminous United States - representing a decade of land cover change information. Photogrammetric Engineering \& Remote Sensing, 81(5), 346-354.

Hunt, L. M. (2005a). Recreational fishing site choice models: Insights and future opportunities. Human Dimensions of Wildlife, 10(3), 153-172.

Hunt, L. M., Arlinghaus, R., Lester, N., \& Kushneriuk, R. (2011). The effects of regional angling effort, angler behavior, and harvesting efficiency on landscape patterns ofoverfishing. Ecological Applications, 21(7), 2555-2575.

Hunt, L. M., Boots, B. N., \& Boxall, P. C. (2007). Predicting fishing participation and site choice while accounting for spatial substitution, trip timing, and trip context. North American Journal of Fisheries Management, 27(3), 832-847.

Hunt, L. M., Camp, E., van Poorten, B., \& Arlinghaus, R. (2019a). Catch and noncatchrelated determinants of where anglers fish: A review of three decades of site choice research in recreational fisheries. Reviews in Fisheries Science and Aquaculture, 27(3), 261-286.

Hunt, K. M., \& Ditton, R. B. (1997). The social context of site selection for freshwater fishing. North American Journal of Fisheries Management, 17(2), 331-338.

Hunt, L. M., Haider, W., \& Bottan, B. (2005b). Accounting for varying setting preferences among moose hunters. Leisure Sciences, 27(4), 297-314.

Hunt, L. M., Morris, D. M., Drake, D. A. R., Buckley, J. D., \& Johnson, T. B. (2019b). Predicting spatial patterns of recreational boating to understand potential impacts to fisheries andaquatic ecosystems. Fisheries Research, 211, 111-120.

Hunt, L. M., Sutton, S. G., \& Arlinghaus, R. (2013). Illustrating the critical role of human dimensions research for understanding and managing recreational fisheries within a socio-ecological system framework. Fisheries Ecology and Management, 2O, 111-124.

Johnson, J. L., Rollins, D., \& Reyna, K. S. (2012). What's a quail worth? A longitudinal assessment of quail hunter demographics, attitudes, and spending habits in Texas. National Quail Symposium Proceedings, 112(7), 294-299.

Jorgensen, C. F., Powell, L. A., Lusk, J. J., Bishop, A. A., \& Fontaine, J. J. (2014). Assessing landscape constraints on species abundance: Does the neighborhood limit species response to local habitat conservation programs? PLoS One, 9, e99339. 
Kansas Department of Wildlife, Parks, and Tourism. (2017). Kansas walk-in hunting access program. https://ksdot.maps.arcgis.com/apps/webappviewer/ index.html?id=43e5bg6582704fc6a8abe3b29c159a6f

Karns, G. R., Bruskotter, J. T., \& Gates, R. J. (2015). Explaining hunting participation in Ohio: A story of changing land use and new technology. Human Dimensions of Wildlife Management, 20(6), 484-500.

Kerr, G. N., \& Abell, W. (2016). What are they hunting for? Investigating heterogeneity among sika deer (Cervus nippon) hunters. Wildlife Research, 43(1), 69-79.

Knoche, S., \& Lupi, F. (2007). Valuing deer hunting ecosystem services from farm landscapes. Ecological Economics, 64(2), 313-320.

Knoche, S., \& Lupi, F. (2013). Economic benefits of publicly accessible land for ruffed grouse hunters. Journal of Wildlife Management, 77(7), 1294-1300.

Komppula, R., \& Gartner, W. C. (2013). Hunting as a travel experience: An autoethnographic study of hunting tourism in Finland and the USA. Tourism Management, 35, 168-180.

Korpela, K., Borodulin, K., Neuvonen, M., Paronen, O., \& Tyrväinen, L. (2014). Analyzing the mediators between nature-based outdoor recreation and emotional well-being. Journal of Environmental Psychology, 37, 1-4.

Larson, L. R., Stedman, R. C., Decker, D. J., Siemer, W. F., \& Baumer, M. S. (2014). Exploring the social habitat for hunting: Toward a comprehensive framework for understanding hunter recruitment and retention. Human Dimensions of Wildlife, 19(2), 105-122.

Lone, K., Loe, L. E., Gobakken, T., Linnell, J. D. C., Odden, J., Remmen, J., et al. (2014). Living and dying in a multi-predator landscape of fear: Roe deer are squeezed by contrasting patterns of predation risk imposed by lynx and humans. Oikos, 123, 41-651.

Lucas, F. (2013). Federal agriculture reform and risk management act of 2013.

Machlis, G. E., \& Field, D. R. (200o). National parks and rural development: Practice and policy in the United States. Island Press, University of Michigan.

MacKenzie, J. (1990). Conjoint analysis of deer hunting. Northeastern Journal of Agricultural and Resource Economics, 19(2), 109-117.

Maller, C., Townsend, M., Pryor, A., Brown, P., \& St Leger, L. (2005). Healthy nature healthy people: "contact with nature" as an upstream health promotion intervention for populations. Health Promotion International, 21(1), 45-54.

Manfredo, M. J., Fix, P. J., Teel, T. L., Smeltzer, J., \& Kahn, R. (2004). Assessing demand for big-game hunting opportunities: Applying the multiple-satisfaction concept. Wildlife Society Bulletin, 32(4), 1147-1155.

Marshall, R. W. (2018). H.R. 5022 the voluntary public access improvement act of 2018.

Mayer, M., Müller, M., Woltering, M., Arnegger, J., \& Job, H. (2010). The economic impact of tourism in six German national parks. Landscape and Urban Planning, 97(2), 73-82. 
Mecozzi, G. E., \& Guthery, F. S. (2008). Behavior of walk-hunters and pointing dogs during northern bobwhite hunts. Journal of Wildlife Management, 72(6), 1399-1404.

Melo, R. A., Rodriguez, D., \& Zarruk, D. (2018). Package 'gmapsdistance. https:// github.com/rodazuero/gmapsdistance

Metcalf, E. C., Graefe, A. R., Trauntven, N. E., \& Burns, R. C. (2015). Understanding hunting constraints and negotiation strategies: A typology of female hunters. Human Dimensions of Wildlife, 20(1), 30-46.

Miller, C. A., \& Graefe, A. R. (200o). Degree and range of specialization across related hunting activities. Leisure Sciences, 22(3), 195-204.

Montgomery, R., \& Blalock, M. G. (2010). The impact of access, cost, demographics, and individual constraints on hunting frequency and future participation. Academy of Marketing Studies Journal, 14(2), 115-131.

Muth, R.M., \& Jamison, W.V. On the destiny or deer camps and duck blinds: The rise of the animal rights movement and the future of wildlife conservation. Wildlife Society Bulletin 28(4), 841-851.

Munn, I. A., Hussain, A., Spurlock, S., \& Henderson, J. E. (2010). Economic impact of fishing, hunting, and wildlife-associated recreation expenditures on the Southeast U.S. Regional economy: An input-output analysis. Human Dimensions of Wildlife, 15(6), 433-449.

Nebraska Game and Parks Commission (2015). 2015 Upland game hunting outlook. https://outdoornebraska.gov/wp-content/uploads/2015/11/2015Nebraska-Upland-Forecast.pdf

Nebraska Game and Parks Commission (2016). The berggren plan: Nebraska's mega plan improving pheasant hunting. http://outdoornebraska.gov/ pheasantplan.

Nebraska Game and Parks Commission (2017a). Public access atlas. http:// outdoornebraska.gov/publicaccessatlas/.

Nakagawa, S., \& Schielzeth, H. (2012). A general and simple method for obtaining R2 from generalized linear mixed-effects models. Methods in Ecology and Evolution, 4(2), 133-142.

Nebraska Game and Parks Commission (2017b). Small game guide. http:// outdoornebraska.gov/guides/.

Nebraska Game and Parks Commission (2017c). Waterfowl guide. http:// outdoornebraska.gov/guides.

Nebraska Game and Parks Commission (2017d). Southwest Nebraska stubble access guide: Addendum to the 2017 public access atlas. http://digital.outdoornebraska. gov/i/885786-2017-stubble-access-guide-addendum-for-web/15.

Nebraska Game and Parks Commission (2018a). Big game guide. http:// outdoornebraska.gov/guides/.

Nebraska Game and Parks Commission (2018b). Turkey guide. http:// outdoornebraska.gov/guides/. 
Nebraska Game and Parks Commission (2018c). Open fields and waters. http://

outdoornebraska.gov/ofw/.

Needham, M. D., \& Vaske, J. J. (2013). Activity substitutability and degree of specialization among deer and elk hunters in multiple states. Leisure Sciences, $33,235-255$.

Nicolaisen, M., Thorsen, K., \& Eriksen, S. H. (2012). Jump into the void? Factors related to a preferred retirement age: Gender, social interests, and leisure activities. International Journal of Aging and Human Development, 75(3), 239-271.

Offenbach, L. A., \& Goodwin, B. K. (1994). A travel-cost analysis of the demand for hunting trips in Kansas. Review of Agricultural Economics, 16(1), 55-61.

Oliver, R. L. (1980). A cognitive model of the antecedents and consequences of satisfaction decisions. Journal of Marketing Research, 17(4), 460-469.

Pang, A. (2017). Incorporating the effect of successfully bagging big game into recreational hunting: An examination of deer, moose and elk hunting. Journal of Forest Economics, 28, 12-17.

Papworth, S. K., Rist, J., Coad, L., \& Milner-Gulland, E. J. (2009). Evidence for shifting baseline syndrome in conservation. Conservation Letters, 2(2), 93-100.

Pollock, K. H., Jones, C. M., \& Brown, T. L. (1994). Angler survey methods and their applications in fisheries management, Vol. 25. Bethesda, MD: American Fisheries Society Special Publication.

Post, J. R., \& Parkinson, E. A. (2012). Temporal and spatial patterns of angler effort across lake districts and policy options to sustain recreational fisheries. Canadian Journal of Fisheries and Aquatic Sciences, 69(2), 321-329.

Poudel, J., Henderson, J. E., \& Munn, I. A. (2016). Economic contribution of hunting expenditure to the southern United States of America. International Journal of Environmental Studies, 73(2), 236-254.

Ribot, J. C., \& Peluso, N. L. (2009). A Theory of access. Rural Sociology, 68(2), 153-181.

Rosenberger, R. S., Sneh, Y., Phipps, T. T., \& Gurvitch, R. (2005). A spatial analysis of linkages between health care expenditures, physical inactivity, obesity and recreation supply. Journal of Leisure Research, 37(2), 216-235.

Rosenberger, R. S., White, E. M., Kline, J. D., \& Cvitanovich, C. (2017). Estimating economic values for estimating outdoor recreation economic benefits from the national forest systemTechnical Report PNW-GTR-957. U.S. Forest Service General.

Rudzitis, G. (1999). Amenities increasingly draw people to the rural west. Rural development perspectives, 14(2), 9-13.

Schroeder, S. A., Fulton, D. C., Lawrence, J. S., \& Cordts, S. D. (2013). Identity and specialization as a waterfowl hunter. Leisure Sciences, 25(3), 218-234.

Schultz, J. H., Millspaugh, J. J., Zekor, D. T., \& Washburn, B. E. (2003). Enhancing sporthunting opportunities for urbanites. Wildlife Society Bulletin, 31(2), 565-573. 
Shrestha, S. K., \& Burns, R. C. (2016). Integrating constraints to the theory of planned behavior in predicting deer hunting participation. Human Dimensions of Wildlife, 21(5), 445-459.

Siemer, W. F., Decker, D. J., \& Stedman, R. C. (2016). Hunter and landowner views on a peri-urban deer-hunting program. Wildlife Society Bulletin, 4O(4), 736-746.

Stedman, R. C., Bhandari, P., Luloff, A. E., Diefenbach, D. R., \& Finley, J. C. (2008). Deer hunting on Pennsylvania's public and private lands: A two-tiered system of hunters? Human Dimensions of Wildlife, 13(4), 222-233.

Stuber, E. F., Gruber, L. F., \& Fontaine, J. J. (2017). A Bayesian method for assessing multi-scale species-habitat relationships. Landscape Ecology, 32(12), 2365-2381.

The R Core Development Team (2018). The R project for statistical computing. https://www.r-project.org/

Truong, T., Adamowicz, W., \& Boxall, P. C. (2018). Modelling the effect of chronic wasting disease on recreational hunting site choice preferences and choice set formation over time. Environmental and Resource Economics, 70, 271-295.

U.S. Census Bureau. (2010). 2010 census: Nebraska profile. https://www2.census. gov/geo/maps/dc10 thematic/2010_Profile/2010_Profile_Map_Nebraska.pdf.

U.S. Census Bureau. (2016). American community survey. https://www.census. gov/acs/www/data/data-tables-and-tools/data-profiles/2016/

$<$ U.S. Census Bureau. (2018). Annual estimates of the resident population: April 1, 2010 to july 1, 2017 - United States - metropolitan and micropolitan statistical area; and for Puerto Rico. https://factfinder.census.gov/faces/tableservices/ jsf/pages/productview.xhtml? src=bkmk.

U.S. Department of Energy. (2005). Model year 2005 fuel economy guide. https:// www.fueleconomy.gov/feg/pdfs/guides/FEG2005.pdf.

U.S. Energy Information Administration. (2018). Gasoline and diesel fuel update. https://www.eia.gov/petroleum/gasdiesel/.

U.S. Fish and Wildlife Service. (2018). 2016 national survey of fishing, hunting, and wildlife-associated recreation. https://www.census.gov/library/ publications/2018/demo/fhw-16-nat.html.

U.S. General Services Administration. (2018). Per diem rates. https://www.gsa. gov/travel/plan-book/per-diem-rates.

U.S. Geological Survey. (2018). The public land survey system (PLSS). https:// nationalmap.gov/small scale/a plss.html.

U.S. Government Office of Management and Budget. (2013). Fiscal year 2013 appendix, budget of the. U.S. Government.

Von Essen, Erica (2018). The impact of modernization on hunting ethics: Emerging taboos among contemporary Swedish hunters. Human Dimensions of Wildlife, 23(1), 21-38.

Wallace, M. S., Stribling, H. L., \& Clonts, H. A. (1991). Effect of hunter expenditure distribution on community economies. Wildlife Society Bulletin, 19(1), 7-14. 
Western Association of Fish and Wildlife Agencies Mule Deer Working Group (2016). 2016 Range-wide status of mule deer and black-tailed deer. https:// www.wafwa.org/Documents\%20and\%20Settings/37/Site\%20Documents/ Working\%20Groups/Mule\%20Deer/Publications2/2016 Mule Deer and BTD_Status_Update_Final.pdf.

West, P. C., \& Merriam, L. C. (1970). Outdoor recreation and family cohesiveness: A research approach. Journal of Leisure Research, 2(4), 251-259.

White, E., Bowker, J. M., Askew, A. E., Langner, L. L., Arnold, J. R., \& Donald, B. K. (2016). Federal outdoor recreation trends: Effects on economic opportunities. Gen. Tech. Rep. PNW-GTR-945. Portland, OR. Pacific Northwest Station: U.S. Department of Agriculture, Forest Service.

Whitten, S. M., \& Bennett, J. W. (2002). A travel cost study of duck hunting in the upper south east of South Australia. Australian Geographer, 33(2), 207-221.

Winkler, R., \& Warnke, K. (2013). The future of hunting: An age-period-cohort analysis of deer hunter decline. Population and Environment, 34(4), 460-480.

Zabriskie, R. B., \& McCormick, B. P. (2004). The influences of family leisure patterns on perceptions of family functioning, 50(3) 281-28.

Zhang, D., Hussain, A., \& Armstrong, J. B. (2006). Supply of hunting leases from nonindustrial private forest lands in Alabama. Human Dimensions of Wildlife, 11(1), 1-14. L.S. Wszola, et al. Journal of Outdoor Recreation and Tourism 29 (2020) 10025613 